\title{
Postnatally presented and spontaneously resolved congenital pulmonary airway malformation in a preterm baby
}

\author{
Zahreddin Guma Abusalah, 1 Moustafa Shehab, ${ }^{2}$ Abdelazeim Abdalla, ${ }^{1}$ \\ Ghassan Nakib Nakib ${ }^{3}$
}

${ }^{1}$ Neonatal Intensive Care Unit, Mediclinic City Hospital, Dubai, United Arab Emirates ${ }^{2}$ Radiology, Mediclinic City Hospital, Dubai, United Arab Emirates

${ }^{3}$ Paediatric Surgery, Mediclinic City Hospital, Dubai, United Arab Emirates

Correspondence to Dr Zahreddin Guma Abusalah, zahreddin.abusalah@mediclinic. ae

Accepted 28 February 2019

\section{DESCRIPTION}

A preterm female infant was delivered by caesarean section at $28^{+1}$ weeks of gestation because of restricted growth. She was the first twin of dichorionic diamniotic twins. Her birth weight was $0.970 \mathrm{~kg}$. Her antenatal scans were all normal. She was ventilated for 5 days. The initial chest X-ray (figure 1) was consistent with moderate respiratory distress syndrome. There was a small cyst within the right lower lobe deemed insignificant at that time. She was extubated to receive non-invasive ventilation in the form of nasal intermittent positive pressure ventilation, nasal continuous positive airway pressure ventilation and heated humidified highflow nasal cannula (HHHFNC) therapy.

While she was on HHHFNC, she developed signs of increased respiratory distress on day 39 of life. Chest X-ray (figure 2A) revealed right lower lobe pseudocystic changes.

Three days later, a contrast CT scan of the chest (figure 2B) was suggestive of congenital pulmonary airway malformation type 2 (congenital cystic adenomatoid malformation type 2) at the level of the right lower lobe. ${ }^{1}$

The case of this baby was managed conservatively. Her respiratory distress has gradually improved over a period of 4 weeks. The HHHFN was weaned off and discontinued. A repeat chest $\mathrm{X}$-ray (figure 3A) showed radiological resolution of the condition. She was allowed home with no clinical signs of respiratory distress.

On regular follow-up, she continued to be asymptomatic. CT scan of the chest (figure 3B) was performed later at 10 months of age. It confirmed the radiological resolution of the condition.

Few antenatally detected cases of this condition have shown spontaneous resolution in the postnatal

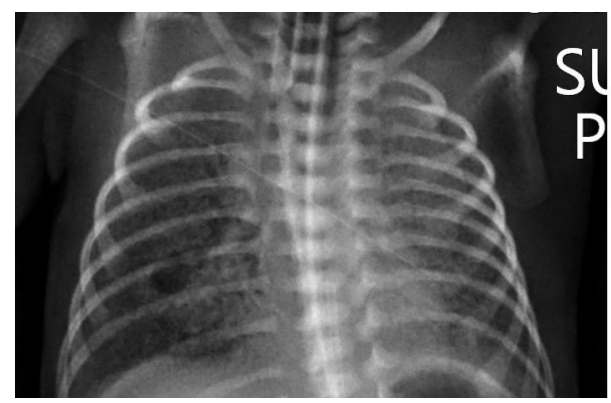

Figure 1 Chest X-ray showing changes consistent with moderate respiratory distress syndrome.

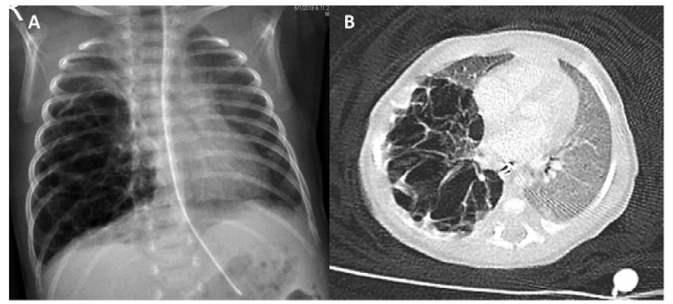

Figure 2 (A) Chest X-ray demonstrating right lower lobe pseudocystic changes. (B) Axial view contrast CT scan of chest illustrating multiple thin-walled cysts containing air (all the cysts are less than $2 \mathrm{~cm}$ ) at the level of the right lower lobe which is suggestive of type 2 congenital pulmonary airway malformation of the right lung.

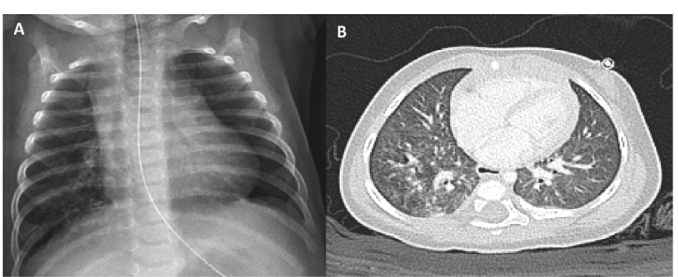

Figure 3 (A) Chest X-ray with radiological resolution of the condition. (B) Repeat axial view contrast CT scan of chest performed 8 months later with resolved congenital pulmonary airway malformation changes.

period. ${ }^{2}$ However, this preterm baby has presented with this condition at 5 weeks of age. Clinical and radiological resolution has occurred a month later without any surgical intervention.

\section{Learning points}

- Congenital pulmonary airway malformations (CPAMs) can present in premature baby several weeks after birth despite normal antenatal scans.

- CPAMs may undergo spontaneous resolution after symptomatic postnatal presentation.

- Conservative management may be safely considered in symptomatic patients with CPAMs. 
Contributors ZGA drafted and wrote the manuscript. AA, MS and GN revised and approved the manuscript. MS prepared the images. ZGA, AA and GN treated and followed the patient.

Funding The authors have not declared a specific grant for this research from any funding agency in the public, commercial or not-for-profit sectors.

Competing interests None declared.

Patient consent for publication Parental/guardian consent obtained.
Provenance and peer review Not commissioned; externally peer reviewed.

\section{REFERENCES}

1 Stocker JT. Congenital pulmonary airway malformation: a new name and expanded classification of congenital cystic adenomatoid malformation of the lung. Histopathology 2002;41(Suppl):424-31.

2 Butterworth SA, Blair GK. Postnatal spontaneous resolution of congenital cystic adenomatoid malformations. J Pediatr Surg 2005;40:832-4.

Copyright 2019 BMJ Publishing Group. All rights reserved. For permission to reuse any of this content visit

https://www.bmj.com/company/products-services/rights-and-licensing/permissions/

BMJ Case Report Fellows may re-use this article for personal use and teaching without any further permission.

Become a Fellow of BMJ Case Reports today and you can:

- Submit as many cases as you like

- Enjoy fast sympathetic peer review and rapid publication of accepted articles

Access all the published articles

Re-use any of the published material for personal use and teaching without further permission

For information on Institutional Fellowships contact consortiasales@bmjgroup.com

Visit casereports.bmj.com for more articles like this and to become a Fellow 